\title{
Economic Development and Sultan Zainul Abidin in Kashmir
}

\author{
Dr Syed Damsaz Ali Andrabi (Corresponding author) \\ Higher Education Department Jammu and Kashmir \\ India
}

E-mail: damsaz.andrabi@gmail.com

Received: December 27, 2015 Accepted: March 3, 2016 Published: June 24, 2016

doi:10.5296/ijch.v3i1.9653 URL: http://dx.doi.org/10.5296/ijch.v3i1.9653

\begin{abstract}
Among all nations and races that have come into contact with Kashmir none of them has left everlasting impact on culture of the Valley as Central Asia. Contacts with Central Asia were developed long before the political domination of Muslims. The foundation of Shah Miri opened the floodgates for the infiltration of Persian and Central Asian people in Valley of Kashmir especially during the reign of Sultan Zainul Abidin. When he ascended the throne in (823.A.H./1420.A.D) the whole administrative machinery had collapsed due to the narrow policy of Sultan Sikandar and Sultan Ali Shah but he reconstructed it successfully. His assiduous work turned Valley of Kashmir into industrial garden. Many new arts and crafts were introduced in the Valley of Kashmir. By this way whole Valley was engulfed by peace and prosperity.
\end{abstract}

Keywords: Peace, Education, Social equality, Art and craft, Industries etc

Zainul Abidin was the eighth Sultan of Shah Miri dynasty. The Sultan ruled over Kashmir for a period of fifty years (823-874.A.H. /1420-70.A.D.) A modern historian, M.Hassan: writes"of all the Sultans who sat on the throne of Kashmir, Zainul Abidin was undoubtly the greatest". He ushered in a period of nearly half a century of peace, prosperity, and benevolent rule for his people. He introduced many arts and crafts for which Kashmir has become famous ever since. When he ascended the throne in (823.A.H./1420.A.D.) the whole administrative machinery of Sultan Sikandar(791-816.A.H./1389-1413.A.D). and his son Sultan Ali Shah(816-23.A.H/1413-1420.A.D) had got collapsed due to their narrow policy. But he reconstructed it successfully. He also took series of measures for the betterment of people irrespective of religion, and thus earned the great name of Bud-Shah ${ }^{1}$ (Great King). 
He was also known by the name of Akbar of Kashmir. He developed agriculture by building the network of canals ${ }^{2}$, dams $^{3}$ and bridges ${ }^{4}$. He himself was a great scholar and several books were translated ${ }^{5}$ during his time. He provided every sort of support and encouragement to learners. He developed the trade and commerce of the country. He also maintained friendly relation with the neighboring rulers such as, Khurasan, Turkistan, Egypt, and Mecca, Tibet etc.and also annexed a large territory into the kingdom of Kashmir.

Having been the loved son $^{6}$ of his father, he received good education both at home and outside. He took great pleasure in traveling, and it was during his father's time that he got an opportunity to visit in the court of Timur $^{7}$ at Samarqand. He remained in the court of Timur for several years and became fully trained of some new arts and crafts of Central Asian origin. His main aim was the peace and prosperity of the country and for that purpose he introduced several reforms. His reign was an era of glory and all-round prosperity for the people of Kashmir. His reforms touched all aspects of life social, economic, political, religious and cultural $^{8}$.

Chronological order of Shah Miri dynasty (Sultans) upto Sultan Zainul Abidin.

1. Sultan Shamsu'd-din-740-743. A. H/1339-42.A. D.

2. Sultan Jamsheed.-743. A. H/1342.A. D.

3. Sultan Alauu'd-din.-743-755. A. H/1342.1354.A. D.

4. Sultan Shihabu'd-din.-755-775. A. H/1354.-1373.A. D.

5. Sultan Qutubu'd-din-775-791. A. H/1373.-1389.A. D.

6. Sultan Sikandar-791-816. A. H/1389.-1413.A. D.

7. Sultan Ali Shah-816-823. A. H/1413-1420.A. D.

8. Sultan Zainul Abidin-823-874.A.H /1420-1470.A. D.

The most significant and memorable contribution of Zainul Abidin was that he provided every sort of encouragement and patronage to the artists and craftsmen. Large number of arts and crafts for which Kashmir has been famous throughout the world, were introduced from Persia for the first time during the time of Sultans, particularly during the golden era of Sultan Zainul Abidin.Some of the arts and crafts which were then unknown in most parts the central Asia were existing in Kashmir during his time. Even after a century when Babar's cousin, Mirza Haider Daulghat ${ }^{9}$ (947-58.A.H./1540-51.A.D) ,invaded Kashmir, he wrote in Tarikhi-Rashidi: "In Kashmir one meets with all these arts and crafts which are in most cities uncommon, such as stone polishing, stone cutting, bottle making window cutting, gold beating etc. In the whole Maver-ul-Nahir (Khurasan) except in Samarkand, and Bokhara, these are nowhere to be met with, while in Kashmir ${ }^{10}$ they are in abundance. This is all due to Zain-ul-Abidin." No doubt some arts and crafts were existing during the Hindu rule, but these had decayed with the down fall of Hindu rule. The invasion of Dalucha ${ }^{11}$ in (1320.A.D) has resulted in the death of large number of artists and craftsmen.Death and fear proved devastating in the field of art. Sultan Sikander and Sultan Ali destroyed what ever was 
left.Zainul Abidin revived and reorganized all these arts and crafts which were destroyed during the course of time.

For the promotion of arts and crafts he used novel methods for this purpose. He provided every sort of patronage to the foreign artists and craftmen, due to which a large number of artists and craftsmen thronged into the Valley. Every sort of arrangement was made for them and they were also motivated to settle down permanently in the Valley along with their families. If any artist wished to leave after a short stay, he was supposed to train the local men in his art, and after that he was allowed to leave the Valley ${ }^{12}$.The Sultan invited competent teachers from various countries to Kashmir, so that they could train people here. If any local was willing to go outside to receive training in the various designs and styles of art, he was provided every sort of help, and also it was also the duty of king to look after his family.

Because of the liberal approach and facilities, Sultan turned Kashmir into an industrial garden. As a result there was tremendous development in the Valley. Above all significant progress was made in the fields such as, glass making, silk ${ }^{13}$, shaw ${ }^{14}$ and $\operatorname{carpet}^{15}$ weaving, paper machie ${ }^{16}$ wood carving ${ }^{17}$, paper making and book binding ${ }^{18}$. Before the introduction of these arts and crafts Kashmir was poor in industrial sector, so much so that even loom was not indigenously found in the Valley. According to noted writer Shrivara, it was introduced by the Persian craftsmen ${ }^{19}$. For the first time weavers brush and loom and the weaving of silk cloth ${ }^{20}$ was introduced during his time. The art of making pashmina was most probably imported from Tibet for which Kashmir is still famous. The art of making bridges ${ }^{21}$ in the country was also the contribution of Persian artists during the time of Zainul Abidin. To train the locals in the art of paper making and book binding, Sultan sent two persons out of Kashmir to Samarkand $^{22}$ to receive the training in these arts and crafts .During their stay in Samarkand, one of them learned the art of paper making, while the other learnt book binding. When they returned to Kashmir they taught these arts to others. Paper ${ }^{23}$ making arrangement was made in Phag pargana. The artist was also given a village as jagir ${ }^{24}$. while another Village was given to book binder. The art of fire works was also introduced during his time, and a person named $\mathrm{Habib}^{25}$ was trained for this purpose. It was due to the efforts of Sultan that many locals learnt the art of fire making, and as a result new weapons were made locally. Not only fire works but the Kashmiris were also fascinated by the vocal and instrumental music of Persia. The instruments like, rabab, sitar, duhal, sunray, duff ${ }^{26}$ etc.were also introduced by the immigrants during the time of Zainul Abidin .The sultan reintroduced the art of drama and dancing which had suffered due to the Puritanism of Sikander.Many actors and dancers both men and women came to $\mathrm{Kashmir}^{27}$ at his invitation. Festivals were held at different places in the Valley such as, Pampore, Bijbehara, Anantnag, Baramulla and etc.There was all-round and tremendous development in social, political, economic and religious aspects of the society.

Sultan was the religious tolerant ruler; it was the chief glory of his rule that there was no discrimination among the subjects on the basis of caste colour and creed. The earlier Sultans had imposed many restrictions on the non Muslims. But all the restrictions were abolished by the great Sultan of the Kashhmir.They were given full freedom to perform their festivals in accordance with their traditions and customs. Now they were free to apply tilak on their 
forehead, put on their dress according to Hindu customs and to educate their children ${ }^{28}$. The rate of the jazia was also reduced from two pals of silver to one masha, but later on it was totally abolished with the passage of time. Due to his policy of religious tolerance, his court always remained full of learned scholars and Sufis both of foreign and local origin. These include among others, Mulla Ahmad, Syed Mohammad Rumi, Syed Shamsu'd- din Andrabi, Qazi Syed Ali Sherazi, Syed Mohammad Sistani, Jonaraja, Srivara and etc.

Syed Shamsu'd-din Andrabi son of Syed Baduru'd-din Ibrahim Andrabi was the spiritual guide of Sultan Zainul Abidin ${ }^{29}$ whose ancestors ${ }^{30}$ had migrated to Kashmir from (Andrab) ${ }^{31}$ Afghanistan in the wake of missionary activities of Mir Sayyid Ai Hamdani during the rule of Sultan Qutubu'd -din (775.-791.A.H./1373-89.A.D.). He received his early Islamic education from his father and memorized the whole Quran at the age of only ten years; he was having no interest in the material desires of the world. Sultan was deeply impressed by his kind and compassionate nature and in-depth understanding of the Islam .He built a mosque ${ }^{32}$ for him near the Khanqahi Andrabia at Malaratta Srinagar in the year( 850 A.H./1447.A.D) . The Khanqah was earlier constructed by the Sultan Qutubu'd-din (775-791.A.H/1373-89.A.D) for his ancestors and later became the centre of Andrabi Syeds in the Valley of Kashmir. Sultan Zainul Abidin used to visit the Khanqahi Andrabia daily to get blessings from Syed Shamsu'd-din. He departed in the year( 932 A.H /1525.A.D) and was buried in the fort of Hariparbat at Srinagar. ${ }^{33}$ The place is best known by the name of Moori.After his departure his son Syed Mir Mirak Andrabi (921-990.A.H./.1515-1582.A.D) carried on the ancestral profession of teaching and preaching. He was the most prominent among the Andrabi Syeds.He was putting up in the Khanqahi Andrabia at Malaratta Srinagar.He was the follower of Qadriya ${ }^{34}$ Sufi order and was among the prominent disciple of Syed Nimat-ullah Shah Qadri, who laid the foundation of Qadriya Sufi order in the Valley of Kashmir in the second half of $16^{\text {th }}$ century during the rule of Chaks (968-994.A.H./1561-1586.A.D.). He traveled to various parts of the Valley for the purpose of propagation of Islam. The society had accepted him as their guide to religious path and advisor in all their day today matters. All his descendents became the followers of Qadriya Sufi order. Syed Mir Mirak Andrabi had three sons; Syed Mohammad (963-1022-A.H./1555-1614.A.D) .Syed Qasim Ahmad Andrabi (971-1040A.H./1563-1631.A.D)Andrabi and Syed Mohammad Yousuf (1001-1063.A.H./1592-1652-3.A.D) .Later on his descendents settled down at every nook and corner of the Valley and benefited the people without any interest and the roots of Qadriya Sufi order were further strengthened almost in all parts where ever they visited. Not only in the Valley but the people outside the Valley were equally benefited.

The impact of foreign skilled workers was not only in the field of arts and crafts, but the Kashmiri language under went a great change. There influence was so profound and deep that the Kashmiris still bear a good deal of its impression. This is strikingly visible in every aspect of Kashmiri life.In the real sense there occurred social changes within the society. All the indicators of change were properly adopted and practised by the Sultan like education, industrialization, secularization, culturalisation and materialistic attitude. In the economic sphere people has entered in the industrial era due to the liberal support of Sultan. In the field of education and introduction of newer trends the moral standard of people really underwent 
many great changes. Education has obviously acted as a tool of revolution in the society. The social change to a greater extent were brought in the Kashmir society through the process of education. Through the process of education their occurred visible changes in the values, attitudes of the people and created a desire of progress. The adoption and diffusion of new techniques resulted in the overall welfare of people and helped a lot in the resettlement of people in the Valley.

Conclusion:Sultan Zaniul Abidin ruled with equity, justice and improved the material prosperity of the people that one can not fail to admire him. His benevolent rule and message of peace demands special homage. Rightly Zainul Abidin was surnamed as Budshah of Kashmir. Because of the glorious contribution his name is still remembered with genuine reverence and gratitude.

\section{References}

1. Foaq Mohammad D., Tarikhi Kashmir, Srinagar, pp.39-40

2. Sultan developed the irrigation system by making a network of canals such as, Kakapur Canal, Chakdar Canal, Karala Canal, Shahkul Canal, Awantipora Canal, Safapur Canal, Pohru Canal, and Mar Canal etc.

Hasan Mohibul, Kashmir under Sultans, Srinagar, 1959, p.84.

3. Shrivara, p.141.

4. In Srinagar he built the first wooden bridge still known by the name of Zaina Kadal.

Kapur, M.L, The history and culture of Kashmir, Jammu, 1992, p.214.

5. The patronage of Sultan attracted scholars from various parts of Persia and Central Asia into Kashmir. Sultan established a translation bareau in which Persian books were translated into Sanskrit and Sanskrit into Persian. By the order of Sultan Mulla Ahmad translated Mahabharata and Kalhanas Rajtarngani into Persian, and the translation of Yousuf -u-zulalkha by Srivara etc.

Hasan Mohibul, Kashmir under Sultans, Srinagar, 1959, pp.88-89.

6. He was the son of Sultan Sikander and belonged to Shah Miri dynasty.

Bamzai P.N.K., Cultural and political history of Kashmir, Srinagar, Vol, II, 2007, p.31.

7. Timur belonged to Seljuk tribe of the Turks. He invaded India in 1398.A.D.his main aim was to loot and plunder the wealth of India. He spends much of the looted wealth in beautifying the Samarkand.

8. Hasan Mohibul, Kashmir under Sultans, Srinagar, 1959, pp.82-83.

9. He ruled on Kashmir for a period of eleven years (947-58.A.H./1540-1551.A.D.).He introduced several new arts and crafts. The hot bath system (Garam Hamam) was also introduced by him. New cities and towns were also founded. 
Kapur, M.L. The history and culture of Kashmir, Jammu, 1992, pp.240-241.

10. Bamzai P.N.K., Cultural and political history of Kashmir, Srinagar, Vol, II, 2007,

11. Hasan Mohibul, Kashmir under Sultans, Srinagar, 1959, p.92

12. Kapur, M.L. The history and culture of Kashmir, Jammu, 1992, pp.216-217

13. Singh N.K., Islamic heritage of Kashmir, vol.ii, Srinagar, p.105.

14. Shal is actually the Persian word, which later on became Kashmiri Shawl.

15. Zanial Abidin brought from Samarkand some carpet weavers and thus came into existence in Kashmir the carpet weaving industry. The carpet industry has given employment to a considerable number of shawl weavers, and some are employed in the making of namdas.the best felts are imported from Yarkand to Kashmir.

Hasan Mohibul, Kashmir under Sultans, Srinagar, 1959, pp.92-93.

16. Srinagar has earned a great reputation in the work of paper machie.the artists of the work were known as Nakash.the paper machie is also known as Kar-i-kalamddani.

Hasan Mohibul, Kashmir under Sultans, Srinagar, 1959, pp.92-93.

17. Various designs have been introduced in Kashmir, by the Central Asian artists such as, Khatamband, Arches, and Mehrabs etc.during the time of Zainul Abidin.

18. Bamzai P.N.K., Cultural and political history of Kashmir, Srinagar, Vol.II, 2007, p.34

19. Deambi Kaul, B.K., Kashmir and Central Asia, Srinagar, 1989, p.111.

20. Hasan Mohibul, Kashmir under Sultans, Srinagar, 1959, p.92

21. During the reign of early rulers there was no permanent bridges, instead boats were used for this purpose. Thus the system of permanent bridges based on contilever, which were in vogue, was the contribution of Persian artisans during the rule of Zainul Abidin.

22. Hasan Mohibul, Kashmir under Sultans, Srinagar, 1959, p.92.

23. Kapur, M.L. The history and culture of Kashmir, Jammu, 1992, pp.217.

24. Lawrence W., The valley of Kashmir, p.380. Says paper workers were settled in Naushahra (Srinagar) and as such there were thirty such families during his time.

25. Hasan Mohibul, Kashmir under Sultans, Srinagar, 1959, p.93.

26. Deambi Kaul, B.K., Kashmir and Central Asia, Srinagar, 1989, pp.112-113.

27. Singh N.K., Islamic heritage of Kashmir, Srinagar Vol., II, p.40.

28. Kapur, M.L. The history and culture of Kashmir, Jammu, 1992, pp.217-218.

29. Foaq, Mohammad-din, Tarikhi Budshahi, Srinagar, 1928, pp.404-405.

30. Ahmad Syed, Tohfa Syed, Mss, pp.3-4.Research library University of Kashmir. 


\section{Macrothink}

Gamgeen Shams-ud-din, Ganealogical table of Andrabi Syeds, Srinagar, pp.1-2.

31. Andrab is the name of a large stream in Afghanistan and of the Valley it empties into, the stream which originates in the Hindu Kush, near Khawak Pass and flows to the west for about 75 miles before merging into the Surkhab.Together, the two streams form a long, narrow Valley. The upper part of that Valley is also called Andrab, the lower part alternately as Khinjan or Doshi Both parts of the Valley had been united governmentally under a single leader, or hakim, who resided at Banu.

Qadri Mohd.S.S. Majmul-al-Buldan, urdu.trans. Vol,I, Srinagar, 2005, pp.108-109.

32. Miskeen Ghulam Mohi-ud-din, Tarikhi Kabir, Srinagar, 1323, pp.31- 33.

33. Tahiri, Peerzada Khaliq, Tazikirai Auwaliya, Kashmir, Vol, 1, Urdu trans., 2003, p.209.

34. Rafiqi A.Q., Sufism in Kashmir, Srinagar, 1976.pp.154.155.

\section{Copyright Disclaimer}

Copyright for this article is retained by the author(s), with first publication rights granted to the journal.

This is an open-access article distributed under the terms and conditions of the Creative Commons Attribution license (http://creativecommons.org/licenses/by/3.0/). 